\title{
RAJATONTA AIKUISOPISKELUA
}

Viime syksynä kymmenen Helsingin yliopiston Lahden tutkimus- ja koulutuskeskuksen sekä Turun yliopiston täydennyskoulutuskeskuksen työntekijää opiskeli ja suoritti PennState Universityn opetusohjelmaan kuuluvan kurssin "Course Design and Development in Distance Education'. Suomalaisten opiskelutovereina oli kaksitoista yhdysvaltalaista aikuiskasvatustieteen jatko-opiskelijaa.

Kurssi sisälsi 45 tuntia puhelinopetusta, laajan harjoitustyön sekä jatkuvan, välillä päivittäisen yhteydenpidon opettajan kanssa. Kaikki opiskelijat osallistuivat opetukseen omalla paikkakunnallaan. Suomalaiset opiskelijat kokoontuivat Lahdessa, Helsingissä ja Turussa. Yhdysvaltalaiset opiskelivat kolmella paikkakunnalla eri puolilla Pennsylvanian osavaltiota.

Miten tämä kaikki toteutettiin? Kuinka suomalaisten onnistui suorittaa yhdysvaltalaisen yliopiston opetussuunnitelmaan kuuluva arvosanaopetus yli valtameren?

Kurssin järjesti PennState University ja opettajana toimi kansainvälisesti arvostettu etäopetuksen asiantuntija, apulaisprofessori Michael Moore. Opetuksen toteuttamisessa käytettiin hyväksi nykyaikaisia monimuoto-opetuksen menetelmiä: puhelinopetusta, sähköpostia, telefaxia ja tavallista pikapostia.

Opetuksen runko muodostui seitsemästä joka toinen viikko järjestetystä seminaari-istunnosta, joiden aikana opiskelijaryhmät olivat yhteydessä toisiinsa puhelinlinjojen välityksellä. Nämä audio-opetustilanteet kestivät kerrallaan kuusi tuntia. Aikaerosta johtuen suomalaiset saivat aivan uuden ulottuvuuden lauantai-iltojen viettoon, sillä opetus alkoi kello 16 ja päättyi kello 22 . Ennakkoon tuo ajankohta tuntui miltei mahdottomalta, mutta jo ensimmäisellä kerralla opiskelu vei mukanaan niin, ettei ajankohtaa tullut tilaisuuden aikana ajatelleeksi.

Audio-opetuksen aikana kaikissa ryhmissä oli Suomeen auki yksi puhelinlinja, joka linkitettiin kaikkiin suomalaisiin ryhmiin Telen puhelinsillan välityksellä. Kaikki ryhmät kuulivat kaikkia yhtä hyvin ja välillä keskustelu kävi erittäin vilkkaana. Unohtui, että osa opiskelijoista oli toisella mantereella. Audio-opetus jaksottui opettajan alustukseen, opiskelijoiden kysymyksiin, harjoitustöiden käsittelyyn ja ryhmätöihin. Opettaja kiersi vuorotellen eri ryhmissä ja viimeisellä kerralla opetus lähetettiin muihin ryhmiin Helsingin yliopiston kasvatustieteen laitokselta. Kuusi tuntia tuntui joka kerran loppuvan kesken.

Syksyn aikana jokainen ryhmä suunnitteli laajasti itse valitsemastaan koulutusohjelmasta yhden etäopetusmodulin, jonka tuli sisältää kirjallista materiaalia, ääni- tai videonahan sekä tunnin mittaisen puhelinopetuksen. Harjoitustöiden sisällöt vaihtelivat unkarilaisille tarkoitetusta jätehuoltokurssista kodin vaaratekijöiden ennaltaehkäisyyn. Aiheiden moninaisuus loi uskoa siihen, että melkeinpä mitä vain voidaan opiskella etäopetuksena.

Telefaxia ja sähköpostia hyväksikäyttäen kaikki pystyvät säännöllisesti seuraamaan muiden työskentelyä. Ainoastaan ääni- videokasetit lähetettiin pikapostina. Opettajan kanssa oli mahdollista olla vaikka päivittäisessä kontaktissa sähköpostin avulla ja hän antoi myös henkilökohtaista neuvontaa. Samoin kaikki opiskelijat saattoivat pitää yhteyttä toisiinsa.

Kurssi antoi vankkaa kansainvälistä tietoa etäopetuksen järjestämisestä ja toteuttamisesta. Kurssin varsinaisen tavoitteen lisäksi saavutettiin myös muita arvokkaita asioita, mm. kansainvälistyminen toteutui aivan konkreettisesti, samoin suomalaisten opiskelijoiden kielitaito parani kurssin aikana.

Kurssin suorittaminen todisti, että etäopiskelu toisen maan yliopistossa voi olla joustavaa ja jopa edullista. Kustannukset muodostuivat kurssinmaksun lisäksi modeemi-, puhelin- ja postikuluista. Mitään kiinteää välineistöä ei opiskeluun osallistuminen edellyttänyt ja yksittäiset opiskelijat olisivat voineet opiskella koko kurssin halutessaan vaikka kotoa käsin.

Kansainvälisten koulutusohjelmien lisääntyessä on monimuoto-opetuksella ja kaksisuuntaisilla televiestimillä tärkeä asema opetuksen toteuttamisessa. Tällä tavoin saamme kansainvälistä koulutusta Suomeen, mutta voimme myös tarjota suomalaista koulutusta ulkomaille. 